\section{Japanese cuisine-induced hyperthyroidism}

\author{
Gérard Reach, Hélène Bihan, \\ Régis Cohen \\ Department of Endocrinology, \\ Diabetology and Metabolic Diseases, \\ Avicenne Hospital, Bobigny, France
}

\begin{abstract}
We present a 46-year-old man with subclinical hyperthyroidism and low iodine 123 uptake. Three months later, all symptoms resolved on beta blockers only; iodine 123 uptake and hormone levels returned to normal. We suspect that hyperthyroidism was secondary to consumption of kombu, a long dark brown to grayish-black seaweed, in a soup. With the current popularity of Japanese restaurants, this possibility should be kept in mind when investigating the causes of iodine overload.
\end{abstract}

\section{Introduction}

One hundred and fifty $\mu$ g iodine are daily required for hormone synthesis. The thyroid gland has intrinsic regulatory mechanisms that maintain normal thyroid function even in the presence of iodine excess. Iodine intake causes a transient decrease in the synthesis of thyroid hormones for approximately 48 hours. This acute inhibitory and protective effect of iodine on thyroid hormone synthesis, called WolffChaikoff effect, is due in part to a decrease in the sodium iodide symporter (NIS) mRNA and protein expression. ${ }^{1}$ On the contrary, iodine deficiency is a pathogenic factor determining nodular goiter susceptible to overt hyperthyroidism in case of iodine excess. ${ }^{2}$ We present herein a case of hyperthyroidism which may be the first report of Japanese food-induced hyperthyroidism in France.

\section{Case Report}

On July, 2010, a 46-year-old man was referred to one of us for a subclinical hyperthyroidism detected in the context of the regular follow-up of multinodular goiter: TSH was 0.08 mIU/L with normal T3 and T4. There was no cervical pain or any local discomfort. There was no obvious history of iodine intake (medication, radiology contrast agent). Hyperthyroidism symptoms included fatigue, insomnia and unusual nervousness but no weight loss.
There were several cases of multinodular goiter in the family.

Thyroid function tests confirmed the diagnosis: serum concentrations of tri-iodothyronine $\left(\mathrm{T}_{3}\right)$, thyroxine $\left(\mathrm{T}_{4}\right)$, and thyrotropin were $5.3 \mathrm{pmol} / \mathrm{L}, 19 \mathrm{pmol} / \mathrm{L}$, and $0.02 \mathrm{mIU} / \mathrm{L}$ respectively (normal ranges 2.6-5.7 nmol/L, 9-19 $\mathrm{pmol} / \mathrm{L}$, and $0.35-4.94 \mathrm{mIU} / \mathrm{L}$, respectively). Anti TSH-receptor antibodies and anti TPO antibodies were negative. Ultrasonography revealed a multinodular goiter with 2 micronodules and a $15 \times 14 \times 13 \mathrm{~mm}$ nodule in the right lobe, 3 micro-nodules and $12.6 \times 14 \times 10$ and $16 \times 14 \times 12 \mathrm{~mm}$ nodules in the left lobe. A thyroid iodine 123 scintigraphy showed low iodine uptake. Urinary iodine level, assayed 28 days after scintigraphy, was $145 \mu \mathrm{g} / 24$ hours. Thyroglobulin was not assessed. Calcitonin was normal $<2 \mathrm{ng} / \mathrm{mL}$.

The patient's interrogation revealed three dinners in a Japanese restaurant in one week and the consumption of kombu, a long dark brown to grayish-black seaweed, in a soup. His personal project was to become manager of a sushi restaurant. Three months later, all symptoms resolved on beta blockers only, the patient had a normal iodine 123 uptake fixation and TSH reversed to normal.

\section{Discussion}

In 2010, there were in France 1,580 sushi, for 1,750 fast food hamburger, restaurants. ${ }^{3}$ France is a zone of low iodine intake inducing benign multigoiter disease and risk of hyperthyroidism in case of iodine excess. The main causes in France of iodine induced hyperthyroidism are drugs, such as amiodarone, topical antiseptics, expectorants, and radiology contrast agents. Various foods and dietary supplements, including Japanese food such as seaweeds (Kelp and Kombu) have been identified as source of high concentration of iodine $\left(1350 \mu \mathrm{g} / \mathrm{g}\right.$ to $1513 \mu \mathrm{g} / \mathrm{g}$ respectively). ${ }^{4}$ It is noteworthy that the iodine content of Nori (used for maki) is not sufficient to determine iodine excess $(16 \mu \mathrm{g} / \mathrm{g})$. There are reports on some case of hyperthyroidisms following ingestion of seaweed in the form of preparations containing fucus vesiculosus and kombu ${ }^{5}$ and of herbal medicine, including kelp and kelp-containing dietary tablets or tea ${ }^{6-14}$ and one report of two japanese women who developed thyrotoxicosis after having eaten foods, in form of Kombu. ${ }^{15}$ Several cases of neonate hypothyroidism resulted from the maternal ingestion of seaweed or drinking soy milk manufactured with Kombu. ${ }^{16}$

Our patient had hyperthyroidism with a low iodine uptake. He did not report any cervical pain. Anti TSH-receptor antibodies and anti TPO antibodies were negative. It may be a case
Correspondence: Gérard Reach, Service d'Endocrinologie, Hôpital Avicenne, 125 Route de Stalingrad, 93009 Bobigny Cedex, France. Tel. +33.148.955.158 - Fax: +33.148.955.560. E-mail: gerard.reach@avc.aphp.fr

Key words: hyperthyroidism, iodine, kombu, Japanese food.

Conflict of interest: the authors report no conflicts of interest.

Received for publication: 25 September 2011. Accepted for publication: 28 October 2011.

This work is licensed under a Creative Commons Attribution NonCommercial 3.0 License (CC BYNC 3.0).

(C) Copyright G. Reach et al., 2011

Licensee PAGEPress, Italy

Endocrinology Studies 2011; 1:e14

doi:10.4081/es.2011.e14

of painful sporadic thyroiditis, where antibodies are present in only $50 \%$ of the cases, who are mostly women. ${ }^{17}$ However, in this male patient having a multinodular goiter, hyperthyroidism with low 123 iodine uptake may also be explained by iodine overload, since he reported three dinners in a Japanese restaurant where he ingested kombu soup: indeed, the fact that iodine urinary excretion was normal three weeks after this scintigraphy does not rule out a transient iodine excess.

\section{Conclusions}

The case reported herein may represent the first report of Japanese restaurant-induced hyperthyroidism. With the current popularity of Japanese restaurants, this possible effect of Kombu should be kept in mind when investigating the causes of iodine overload.

\section{References}

1. Roti E, Uberti ED. Iodine excess and hyperthyroidism. Thyroid 2001;11:493-500.

2. Valeix P, Faure P, Péneau S et al. Lifestyle factors related to iodine intakes in French adults. Public Health Nutr 2009;12:242837.

3. Baraille C. Le sushi rattrape le hamburger mais reste loin du produit de masse. http://www.google.com/hostednews/afp/art icle/ALeqM5hB6hkvuGZ8oXL7txSqhJZ0Kz qZMA Accessed: 8 Septembre 2011

4. Teas J, Pino S, Critchley A, Braverman LE. 
Variability of iodine content in common commercially available edible seaweeds. Thyroid 2004;14:836-41

5. Picco G, de Dios-Romero A, Albanell N, Badia J. Ingestión habitual de algas e hipertiroidismo. Med Clin (Barc) 2006; 127:199.

6. Müssig K, Thamer C, Bares R et al. Iodineinduced thyrotoxicosis after ingestion of kelp-containing tea. J Gen Intern Med. 2006;21:C11-4.

7. Hartman AA. Hyperthyroidism during administration of kelp tablets. Ned Tijdschr Geneesk 1990;134:1373.

8. de Smet PA, Stricker BH, Wilderink F, Wiersinga WM. Hyperthyroidism during treatment with kelp tablets. Ned Tijdschr Geneesk 1990;134:1373.
9. Eliason BC. Transient hyperthyroidism in a patient taking dietary supplements containing kelp. J Am Board Fam Pract 1998;11:478-80.

10. Salas Coronas J, Cruz Caparros G, Laynez Bretones F, Diez Garcia F. Hyperthyroidism secondary to kelp tablets ingestias. Med Clin (Barc) 2002;118:797-8.

11. Henzen C, Buess M, Brander L. Iodineinduced hyperthyroidism (iodine-induced Basedow's disease): a current disease picture. Schweiz Med Wochenschr 1999;129: 658-64.

12. Eliason BC. Transient hyperthyroidism in a patient taking dietary supplements containing kelp. J Am Board Fam Pract 1998;11:478-80.

13. de Smet PA, Stricker BH, Wilderink F,
Wiersinga WM. Hyperthyroidism during treatment with kelp tablets. Ned Tijdschr Geneeskd 1990;134:1058-9.

14. Shilo S, Hirsch HJ. Iodine-induced hyperthyroidism in a patient with a normal thyroid gland. Postgrad Med J 1986;62:661-2.

15. Ishizuki Y, Yamauchi K, Miura Y. Transient thyrotoxicosis induced by japanese kombu. Nippon Naibunpi Gakkai Zasshi 1989 20;65:91-8.

16. Crawford BA, Cowell CT, Emder PJ et al. Iodine toxicity from soy milk and seaweed ingestion is associated with serious thyroid dysfunction. Med J Aust 2010;193:413-5.

17. Pearce NE, Farwell AP, Braverman LE. Thyroiditis. N Engl J Med 2003;348:2646-55. 